\title{
Optimization of a photovoltaic installation supported with hydrogen. Study of the influence of the tilt angle of the modules.
}

\author{
M. Calderón ${ }^{1}$, A. Ramiro ${ }^{2}$ and J.F. González ${ }^{2}$ \\ ${ }^{1}$ Department of Electrical Engineering. ${ }^{2}$ Department of Applied Physics. \\ E.I.I., Extremadura University \\ Avenida de Elvas s/n, 06078 Badajoz (Spain) \\ Phone/Fax number: +0034 924 289600/01, e-mail: calgodoy@unex.es, aramiro@unex.es
}

\begin{abstract}
The aim of this work is to analyze the influence of the tilt angle of the photovoltaic modules on the efficiency of a autonomous photovoltaic installation isolated from power supply and supported with hydrogen by a Fuel Cell. The photovoltaic modules were oriented to face south in all the cases.
\end{abstract}

\section{Key words}

Photovoltaic solar energy, hydrogen, fuel cell, tilt angle, Proton Exchange Membrane.

\section{Introduction}

Hydrogen as an energy carrier can play an important role as an alternative to conventional fuels, provided that its technical problems of production, storage and transportation, can be resolved satisfactorily and the system cost can be brought down to acceptable limits. One of the most attractive features of hydrogen as an energy carrier is that it can be produced from water, which is abundantly available in nature. One of the simplest practical ways to obtain hydrogen is from water by electrolysis [1]. Hydrogen can be used as a storage medium for intermittent and seasonal renewable technologies. Hydrogen will join electricity in the 21st century as a primary energy carrier in the sustainable energy future. When we speak about hydrogen, we are talking about its production, storage and utilization. Both electricity and hydrogen in the future will be mostly derived from either renewable or nuclear energy sources [2]. Energy storage capacity is a principal issue to increase the conversion efficiency of renewable energies. Storage in batteries is mostly used but their limited capacity and lifetime decrease the utility of renewable system, for instance, in the case of remote applications with high energy demand. The storage capacity, and with it the efficiency of renewable energies, may be increased with the production of hydrogen from water electrolysis, by adding an electrolyser, a hydrogen storage means and a fuel cell. The scheme of the system is shown in Figure 1. It is composed of a photovoltaic generator, a battery set, an electrolyser, a metal-hydride system for hydrogen storage, a fuel cell and a system in charge of supervisory control and data acquisition. In summer, solar energy is enough to power the application, maintain a high state of charge of the batteries and run the electrolyser to produce hydrogen. Hydrogen is stored in the metal hydrides. In winter when the state of charge of the batteries is low, the fuel cell recharges the batteries avoiding a cut in electric power to the application [3].

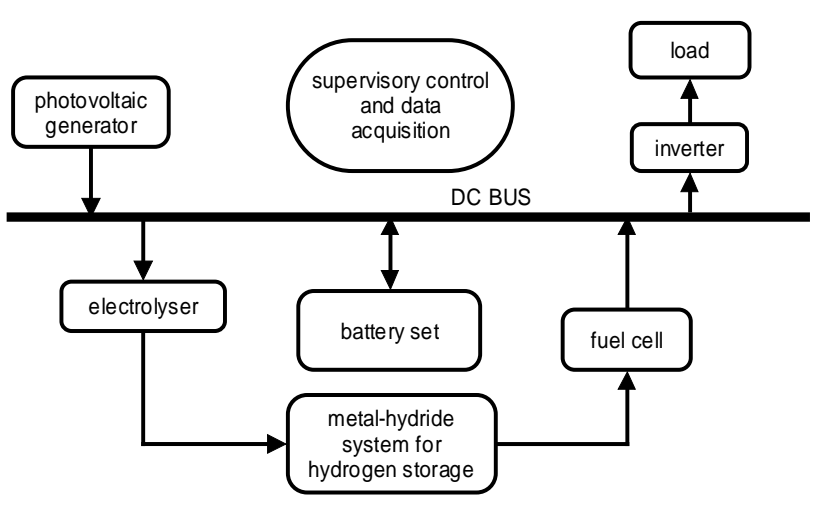

Figure 1. Scheme of the solar hydrogen system

One of the advantages of the type of systems is noninterruption of the electrical energy supply, but, in order to get a competitive system, a reduction of the equipment cost is necessary.

Ever since fuel cells first went into space over 30 years ago one of the largest barriers to their terrestrial use has been their cost; fuel cells have been too expensive to be practical for most applications. In recent years much effort has gone into reducing the cost of those individual components that previously represented the largest share of the cost of proton exchange membrane (PEM) fuel cells and the electrolysers [4].

In the case of hydrogen-supported photovoltaic installations, the tilt of the photovoltaic modules plays an important role not only in the minimum number of photovoltaic modules which are needed to guarantee the autonomous operation of the installation but also in the hydrogen net production during the whole year. 


\section{Influence in the number of modules}

We used the calculation method of the "least favourable month" to determine the size of the photovoltaic installation. When this method is employed, the modules tilt angle influences significantly the number of them that is needed to cover the demand corresponding to this month, as it is revealed in Figure 2. This Figure refers to a photovoltaic installation composed by modules of $110 \mathrm{Wp}$ maximum power rating which supplies energy to a country single-family house that is isolated from power supply, and has an average monthly diary consumption of $6210 \mathrm{Wh}$ /day (Table 1). This house is located in the town "Llerena” (Badajoz) [5].

Table 1. Pattern of energy consumption for family house

\begin{tabular}{|c|c|c|c|c|c|}
\hline Application & $\mathbf{N}^{\circ}$ & $\begin{array}{c}\text { Power } \\
(W)\end{array}$ & $\begin{array}{c}\text { Hours } \\
\text { day }\end{array}$ & $\begin{array}{c}\mathbf{P}_{\mathrm{T}} \\
(\mathbf{W})\end{array}$ & $\begin{array}{c}E \\
\text { (Wh/day) }\end{array}$ \\
\hline Refrigerator & 1 & 80 & 16 & 80 & 1280 \\
\hline $\begin{array}{l}\text { Kitchen } \\
\text { lighting }\end{array}$ & 2 & 20 & 3 & 40 & 120 \\
\hline $\begin{array}{l}\text { Bath } \\
\text { lighting }\end{array}$ & 4 & 20 & 2 & 64 & 160 \\
\hline $\begin{array}{l}\text { Bedroom } \\
\text { lighting }\end{array}$ & 8 & 20 & 1 & 128 & 160 \\
\hline $\begin{array}{l}\text { Washing } \\
\text { machine }\end{array}$ & 1 & 400 & 0,75 & 200 & 300 \\
\hline Microwave & 1 & 1000 & 0,1 & 600 & 100 \\
\hline $\begin{array}{l}\text { Home } \\
\text { appliances }\end{array}$ & 4 & 400 & 0,5 & 400 & 800 \\
\hline T V & 1 & 90 & 3 & 54 & 270 \\
\hline PC & 1 & 300 & 1 & 180 & 300 \\
\hline $\begin{array}{l}\text { Living- } \\
\text { room ligting }\end{array}$ & 4 & 20 & 3 & 80 & 240 \\
\hline Dishwasher & 1 & 1600 & 0,50 & 800 & 800 \\
\hline Video & 1 & 90 & 2,00 & 45 & 180 \\
\hline Iron & 1 & 1500 & 1,00 & 750 & 1500 \\
\hline & & & Total & 3421 & 6210 \\
\hline
\end{tabular}

Since we are considering the worst month in installations that are annually used, a winter month (usually December or January), when the sun reaches a lesser culmination height, this number decreases as the tilt angle is increased (since, in this way, the radiation incidence angle on the photovoltaic modules is diminished) and raises when the tilt angle is reduced or excessively increased.

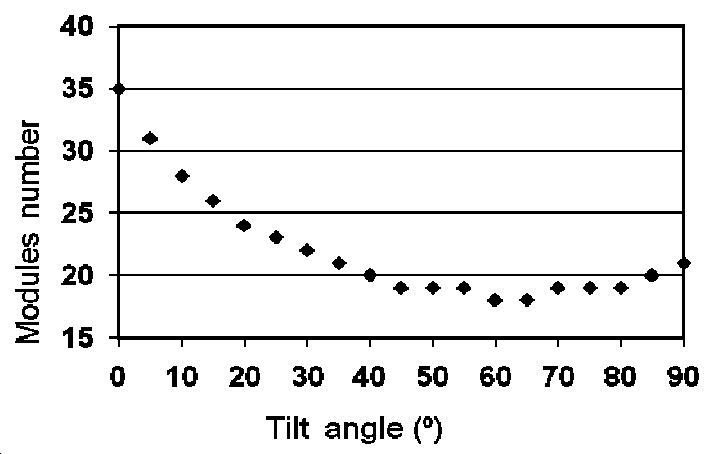

Figure 2. Number of modules of a photovoltaic installation according to the tilt angle.

However, in hydrogen supported photovoltaic installations (with a PEM electrolyser-fuel cell ensemble) [6] this incidence is significantly lower since, if a high tilt angle is used, the production of power is increased during the least radiation months. Consequently, the consumption of hydrogen will be reduced, but also, the quantity of hydrogen produced will be lower in the highest radiation months.

On the contrary, if a low tilt angle is used, the energy supplied by the solar panels in the least radiation months will decrease. Therefore, the consumption of hydrogen will increase in these months (but its production is also raised during this period).

It does not exist, therefore, a direct dependence between the tilt angle and the number of solar panels that are needed to cover the installation consumption but hydrogen works as a shock-absorbing of this relationship reducing this dependence [7].

Figure 3 shows how the tilt angle influences on the number of panels, in the case of the previous house.

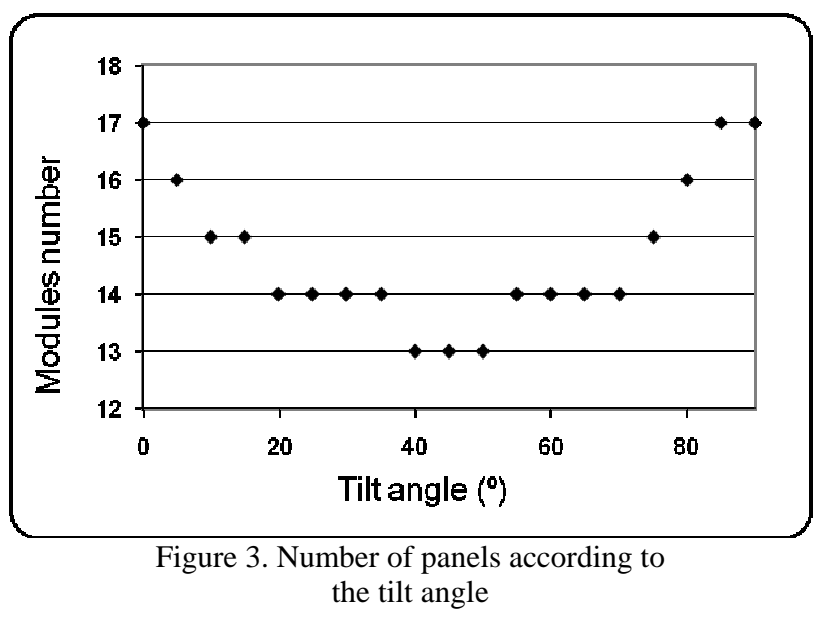

The production and the annual consumption of hydrogen according to the tilt angle in the same installation with 12 photovoltaic panels have been plotted in Figure 4. It is revealed that this number of modules is insufficient independently of the tilt angle used due to the fact that the consumption of hydrogen is always higher than its production.

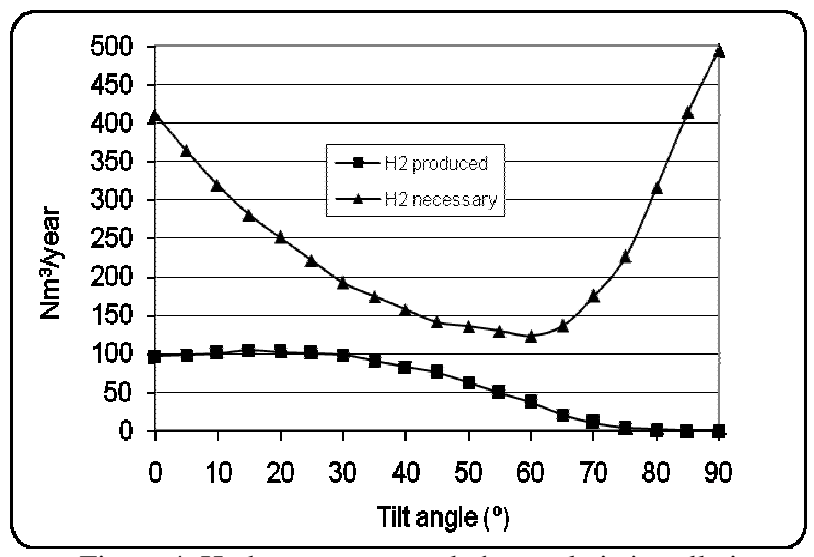

Figure 4. Hydrogen supported photovoltaic installation with 12 modules

If the number of panels is increased by one (13 modules, see Figure 5) then, for an tilt angle in the range $38^{\circ}-50^{\circ}$, 
the annual hydrogen production exceeds its consumption, yielding the highest net hydrogen production for an tilt angle of $45^{\circ}$.

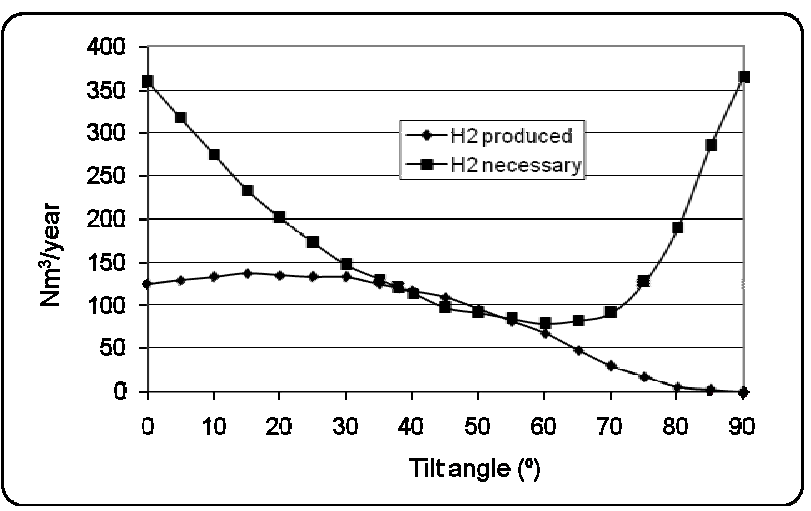

Figure 5. Hydrogen supported photovoltaic installation with 13 modules

As it can be appreciated from Figure 6, the tilt angle range for which hydrogen production is higher than its consumption raises as the number of panels is increased.

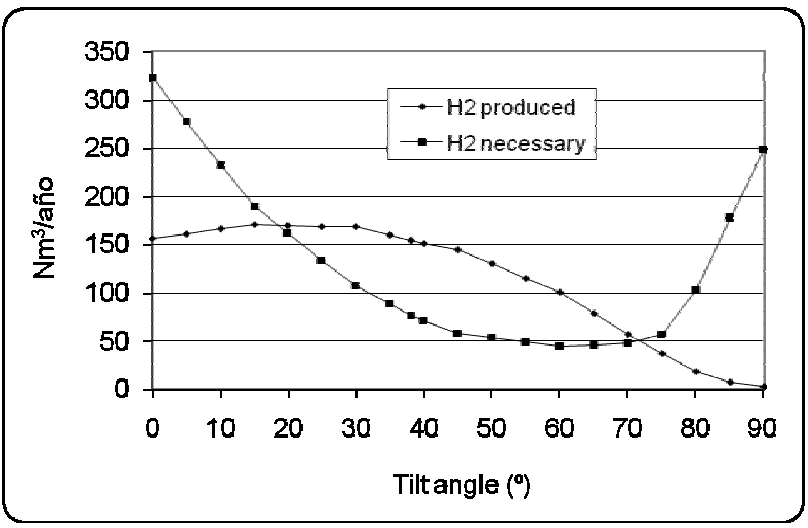

Figure 6. Hydrogen supported photovoltaic installation with 14 modules

This range can take a value between $0^{\circ}$ and $90^{\circ}$ when 17 modules are used, since, in this case, the quantity of hydrogen produced along the whole year always exceeds to the one consumed by the installation.

\section{Influence on hydrogen production}

Table 2 shows the hydrogen production, its consumption and the annual net production of a photovoltaic installation versus the number of modules for a fixed angle ( $45^{\circ}$, which is the one that supplies the highest net hydrogen production, as it has been stated before).

Table 2. Hydrogen net production according to the number of modules with a fixed tilt angle.

\begin{tabular}{|c|c|c|c|}
\hline $\begin{array}{l}\text { Modules } \\
\text { number }\end{array}$ & $\begin{array}{c}\mathrm{Nm}^{3} \mathrm{H}_{2} \\
\text { Produced/year }\end{array}$ & $\begin{array}{c}\mathrm{Nm}^{3} \mathrm{H}_{2} \\
\text { Necessary/year }\end{array}$ & $\begin{array}{c}\text { Net Produced } \\
\left(\mathrm{Nm}^{3} \mathrm{H}_{2}\right)\end{array}$ \\
\hline 12 & 75 & 141 & -67 \\
\hline 13 & 109 & 97 & 11 \\
\hline 14 & 144 & 58 & 86 \\
\hline 15 & 184 & 37 & 146 \\
\hline 16 & 223 & 17 & 207 \\
\hline 17 & 264 & 2 & 263 \\
\hline
\end{tabular}

As expected, the net annual production raises as the number of modules is increased. However, as the tilt angle is fixed, it can not be the angle which produces the highest quantity of hydrogen and the one that consumes the least quantity of it at the same time.

With the aim of producing a higher quantity of hydrogen we could use a lower angle so that during the least radiation months, the incidence angle of this radiation is less. However, if we want to obtain a less hydrogen consumption, the tilt angle should be higher, to cause a higher performance of the modules during the least radiation months.

A way for attaining the previous target is to use two o more tilt angles during the year. In the case of using just two tilt angles we would use one higher angle in order to get a higher power production and hydrogen saving (during the winter months), and a lower angle, which will (during the highest radiation months). Table 3 shows the hydrogen production, its consumption and the net annual production, when tilt angles are of $60^{\circ}$ (from November to March) and $15^{\circ} \mathrm{C}$ (for the remaining months) are used, since these are the angles which supply the highest net hydrogen production.

Table 3. Hydrogen annual net production according to the number of modules with two tilt angles

\begin{tabular}{|c|c|c|c|}
\hline $\begin{array}{c}\text { Modules } \\
\text { Number }\end{array}$ & $\begin{array}{c}\mathbf{N m}^{3} \mathbf{H}_{2} \\
\text { Produced/year }\end{array}$ & $\begin{array}{c}\mathbf{N m}^{\mathbf{3}} \mathbf{H}_{\mathbf{2}} \\
\text { Necessary/year }\end{array}$ & $\begin{array}{c}\mathbf{N e t} \text { Produced } \\
\left.\mathbf{( N m}^{3} \mathbf{H}_{2}\right)\end{array}$ \\
\hline 12 & 107 & 122 & $\mathbf{- 1 5}$ \\
\hline 13 & 142 & 78 & $\mathbf{6 4}$ \\
\hline 14 & 184 & 44 & $\mathbf{1 4 0}$ \\
\hline 15 & 226 & 24 & $\mathbf{2 0 2}$ \\
\hline 16 & 267 & 3 & $\mathbf{2 6 4}$ \\
\hline 17 & 315 & 0 & $\mathbf{3 1 5}$ \\
\hline
\end{tabular}

Table 4 and Figures 7 and 8 show the increase in the hydrogen annual net production according to the number of tilt angles considered. Figure 7 corresponds to a photovoltaic installation of 13 modules and Figure 8 shows the values of the hydrogen annual net production for installations of 14, 15, 16 and 17 modules.

Table 4. Hydrogen annual net production $\left(\mathrm{Nm}^{3} \mathrm{H}_{2} /\right.$ year) according to the number of tilt numbers

\begin{tabular}{|l|r|r|r|r|r|r|}
\hline & \multicolumn{1}{|c|}{$\begin{array}{c}13 \\
\text { modules }\end{array}$} & $\Delta(\%)$ & $\begin{array}{c}14 \\
\text { modules }\end{array}$ & $\Delta(\%)$ & $\begin{array}{c}15 \\
\text { modules }\end{array}$ & $\Delta(\%)$ \\
\hline 1 angle & 11 & & 86 & & 146 & \\
\hline 2 angle & 64 & 481,8 & 140 & 62,8 & 202 & 38,4 \\
\hline 3 angle & 71 & 10,9 & 145 & 3,6 & 209 & 3,5 \\
\hline 4 angle & 71 & 0,0 & 146 & 0,7 & 210 & 0,5 \\
\hline 5 angle & 72 & 1,4 & 148 & 1,4 & 212 & 1,0 \\
\hline
\end{tabular}




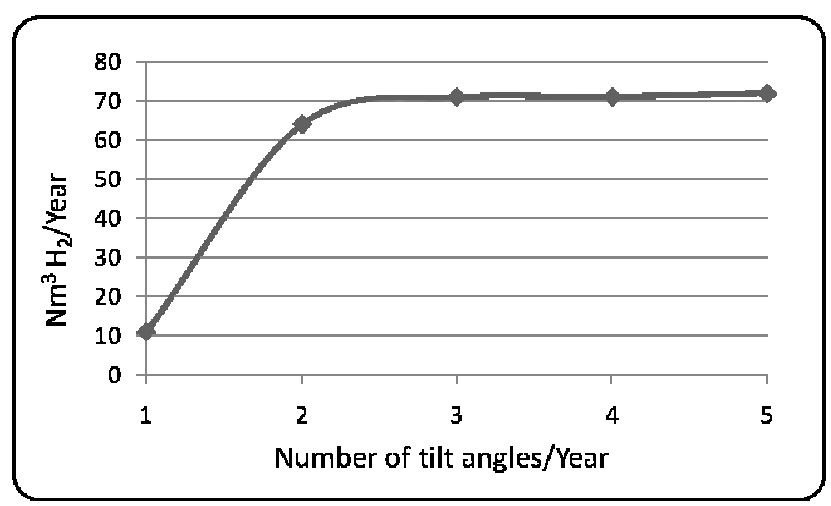

Figure 7. Hydrogen annual net production according to the number of angles for a photovoltaic installation of 13 modules

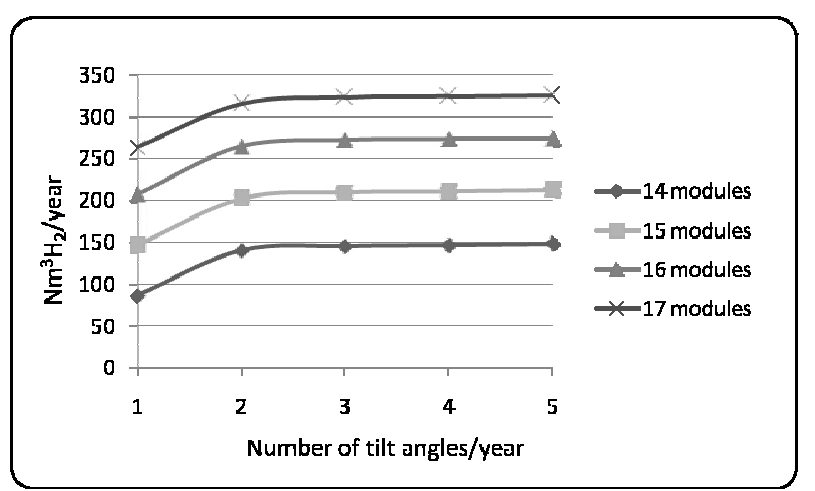

Figura 8. Hydrogen annual net production according to the number of angles for a photovoltaic installation of 14, 15, 16 and 17 modules

\section{Conclusions}

The choice of an adequate tilt angle is important when designing a photovoltaic installation depending on its application, since it can reduce significantly the number of modules needed, especially in the case of those installations which are not supported by hydrogen. The latter, however, the dependence between the number of modules and the chosen tilt angle is much lower since there is a double dependence between this angle and on the one hand the production of hydrogen, and on the other hand, its consumption.

With reference to hydrogen supported photovoltaic installations, the previous Figures reveal the advisability of using two tilt angles in the year $\left(60^{\circ}\right.$ y $\left.15^{\circ}\right)$ during the months indicated in Table 2, due to:

- the increase in production that is attained in comparison with a single angle (481,8 \% with 13 modules), increase that is higher as the modules number gets lower.

- the slight increase in hydrogen production when the annual number of angles is raised to 3,4 y 5 , following a decreasing output law pattern.

The determination of the tilt angles which provide a higher hydrogen net production was made using the solver tool of Excell programme.

These increases in the hydrogen annual net production when two different tilt angles are used in one year, are due to the fact that, achieving a higher solar radiation exploitation with the use of these two angles gives rise, on the one hand to an increase on hydrogen monthly production, and, on the other hand, to a decrease in its monthly consumption, which involves a higher monthly (and thus annual) net production and, as it can be proved by comparing the values of Tables 1 and 2 .

The conventional photovoltaic installations shown in Table 5 and Figure 9, show the increase in power net production according to the number of tilt angles. As it can be observed, the increments produced in this case are much lower than those corresponding to hydrogen supported installations since now; the only effect achieved with the use the more than one tilt angle is to increase the net power production.

Table 5. Annual net power production (kWh/año) according to the number of tilt angles

\begin{tabular}{|c|c|c|}
\hline $\mathbf{N}^{\mathbf{0}}$ of angles & $\begin{array}{c}\text { Production } \\
\text { (kWh/year) }\end{array}$ & $\Delta(\mathbf{\%})$ \\
\hline 1 & 1484 & \\
\hline 2 & 1656 & 11,59 \\
\hline 3 & 1682 & 1,57 \\
\hline 4 & 1689 & 0,42 \\
\hline 5 & 1696 & 0,41 \\
\hline
\end{tabular}

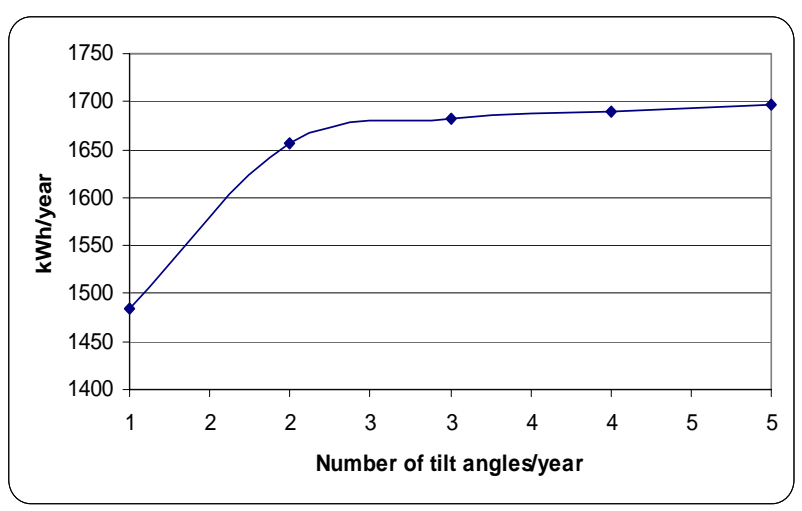

Figure 9. Net power production (kWh/year) according to the number of tilt angles for a photovoltaic installation of 18 modules

\section{Acknowledgements}

The authors thank the Ministerio de Educación y Ciencia of Spain and the Junta de Extremadura for its economic support through the Projects ENE2007/66668/ALT, PRI07A088 and PDT07A047.

\section{References}

[1] Richa Kothari, D. Buddhi, R.L. Sawhney. "Studies on the effect of temperature of the electrolytes on the rate of production of hydrogen". Int J Hydrogen Energy 30 (2005) 261-263

[2] Dragica Lj.Stopjic, Milica P. Marceta, Sofija P Sovilj, Scepan S. Miljanic. "Hydrogen generation from water electrolysis-possibilities of energy saving". Journal of Power Sources 118 (2003) 315319 
[3] A.M.Chaparro, J.Soler, M.J.Escudero, E.M.L. de Ceballos, U.Wittstadt, L.Daza. "Data results and operational experience with a solar hydrogen system". Journal of Power Sources 144 (2005) 165169

[4] Oliver J. Murphy, Alan Cisar and Eric Clarke. "Lowcost light weight high power density PEM fuel cell stack" Electrochimica Acta, Vol.43, No. 24, pp.3829-3840, 1998.

[5] M. Calderón, A. Ramiro, J.F. González, "Estudio de viabilidad de una instalación solar fotovoltaica aislada de la red con apoyo de hidrógeno" in Proc. V JNIT, Vigo (2007), 41 pdf.

[6] M. Calderón, A. Ramiro, J.F. González, S. Román, M. García Machuca, "Obtaining of characteristic curves of PEM electrolyser - fuel cell ensemble", in Proc. XCLEEE (2007), pp. 3.79-3.81.

[7] M. Calderón, A. Ramiro, J.F. González, "Influencia del ángulo de inclinación en el número de paneles de una instalación solar fotovoltaica con apoyo de hidrógeno", in Proc. Tercer Encuentro Sectorial del Hidrógeno y las Pilas de Combustible, Santiago de Compostela, (2008) pp 11H. 